\title{
Thalassemia Control by Awareness: A Study among the Educated Bengalee Populations of South 24 Parganas District,
}

\author{
West Bengal, India
}

\author{
Sudipta Kumar Behera ${ }^{1}$, Sanghamitra Panja ${ }^{1}$, Dipak K. Adak ${ }^{1}$
}

\section{ABSTRACT}

This study is an evaluation of KAP (knowledge, attitude and practice) among the educated Bengalee population of rural West Bengal, India. It reveals a positive perception of the people towards this disorder. Genetic counseling and participation in awareness programme is very poor among these respondents. There is considerable difference between two genders in terms of knowledge like- 'about the child to whom blood is given frequently' and 'thalassemia is a blood related disorder'. More number of males agreed to live with a person suffering from thalassemia than their counterparts. Proper education and awareness programme with local community participation will be very effective as people witness the seriousness of this disease in their day to day life.

Keywords: Knowledge, Attitude And Practice, Thalassemia, Educated Bengalee, India

Thalassemia derived from Greek roots thalassa for 'the sea' and haima for 'blood'. The thalassemias are a diverse group of genetic blood diseases characterized by absent or decreased production of normal hemoglobin, resulting in a microcytic anemia of varying degree. The thalassaemia have a distribution concomitant with areas where Plasmodium falciparum malaria is common. The alpha thalassemias are concentrated in Southeast Asia, Malaysia, and southern China. The beta thalassemias are seen primarily in the areas surrounding Mediterranean Sea, Africa and Southeast Asia. Due to global migration patterns, there has been an increase in the incidence of thalassemia in North America in the last ten years, primarily due to immigration from Southeast Asia.

\footnotetext{
${ }^{1}$ Anthropological Survey of India, 27 Jawaharlal Nehru Road, Kolkata, West Bengal, India

*Responding Author (C) 2016 I S Behera, S Panja, D Adak; licensee IJIP. This is an Open Access Research distributed under the terms of the Creative Commons Attribution License (http://creativecommons.org/licenses/by/2.0), which permits unrestricted use, distribution, and reproduction in any Medium, provided the original work is properly cited.
} 


\section{Thalassemia Control by Awareness: A Study among the Educated Bengalee Populations of South 24 Parganas District, West Bengal, India}

Thalassemia is prevalent in humid climates where malaria is endemic. This disorder is associated with Africans-Americans, people of Mediterranean origin and Asians. There are almost 300 million carriers of hemoglobin disorders in the world, with the minority living in South Eat Asia. Worldwide, the Asian, Indian and Middle Eastern regions account for 95\% of thalassaemia births. The frequency of alfa -thalassemia reaches $25 \%$ in Thailand, and $\mathrm{Hb} \mathrm{E}$ approaches $60 \%$ in many regions of Thailand, Laos and Cambodia.

Beta-thalassemia trait in general population in India is about 3\%. A number of communities in India, such as Sindhi, Lohana, Khoja, Bhanushali, Punjabi, Jain, Muslim and Bengalee among whom the incidence of beta thalassaemia trait ranges from $8 \%$ to $15 \%$. The high incidence can be attributed to consanguinity and endogamy practiced among these communities. It is evident that if awareness about the disease is not created in these communities, the number of beta thalassaemia major children born will be much higher than the present estimate of about 8000 to 10,000 per year (Yagnik, 1997). In India, there are 33\% of thalassemic children, who are from West Bengal. Karimi et al. (2007) reported bone mineral density in beta-thalassemia major and intermedia among the Iranian patients affected by thalassemia. Problems and strategy for prevention and control of thalassemia is described by Fucharoen and Winichagoon (1992). There are studies on thalassemia among the Sardinian (Cao et al., 1991), Vietnamese (Slomp et al., 206), British (Higgs et al., 1985) and South Taiwanese ( Lin et al., 1992) to mention a few. While Durga Devi et al. (2012) described the method of screening analysis techniques and treatment strategies for hemoglobin E beta-thalassemia, Fodde et al. (1988) reported the prevalence and molecular heterogeneity of alfa+ thalassemia in two tribal populations from Andhra Pradesh.

Intensity of this disease is more prevalent in the district of South 24 Parganas and Midnapore in comparison to other districts of West Bengal (Basu, Chakravorty and Chakravorty, 2002). This disease again, is more prevalent in the river line belt of the districts of South 24 Parganas and Midnapore of West Bengal. Thalassemia control is possible by screening of general population for carrier status and antenatal diagnosis in couples identified to be at risk (possibility) of having a child with thalassaemia. Psycho-genetic counseling is communication process of providing information and support to families, couples, or individuals that are in some way impacted by an inherited disease such as thalassemia. As there is no proper medicine of this disease and prevention is the only solution to control this, until and unless of awareness of common mass it is not at all possible to prevent this. In this backdrop an attempt has been made in this study to examine the knowledge, attitude and practice of the educated Bengalee towards thalassemia in South 24 Parganas district of West Bengal, India. 


\section{MATERIAL AND METHODS}

Sample: The study was conducted in Falta Block, Diamond Harbour Block- I and Diamond Harbour Block- II of South 24 Parganas district of West Bengal. This area is considered as highrisk area for thalassemia. Study population, the Bengalee, was drawn from educated background.

Sample size: 261(Two hundred sixty-one), including male and female. Out of 261 subjects, males were 109 and females were 152 in number. Among 152 females one female was excluded being not heard the term thalassemia.

Sampling: Purposive sampling

A structured thalassemia awareness schedule comprising knowledge, attitude and practice, and a general demography schedule was filled in for each of the respondent. Approval for the study was obtained from the Institutional Ethics Committee of the Anthropological Survey of India.

\section{RESULTS AND DISCUSSION}

\section{Prevalence of diseases:}

Information on prevalent diseases in the area is furnished in Table 1. Both the males and females expressed the occurrence of a good number of communicable and non-communicable diseases in their area. The same is true for childhood diseases. But the educated males differ considerably form their counterparts in terms of 'knowledge about the child to whom blood is given frequently'. While, only $22.94 \%$ of the males have the knowledge, $90.73 \%$ of the females know this. Both the genders have the knowledge of different genetic diseases. They are also well aware that these diseases are transmitted from the parents or any other sources.

Table 1: Information about prevalent diseases in the locality

\begin{tabular}{|c|c|c|c|}
\hline \multirow[t]{2}{*}{$\begin{array}{l}\text { Sl. } \\
\text { No. }\end{array}$} & \multirow[t]{2}{*}{ Statements } & \multicolumn{2}{|c|}{$\begin{array}{l}\text { Response (qualitative, No. and percentage: } \\
n=260 \text { ) }\end{array}$} \\
\hline & & Male $(n=109)$ & Female $(n=151)$ \\
\hline 1 & $\begin{array}{l}\text { What kind of diseases the people of your } \\
\text { locality are suffering from? }\end{array}$ & 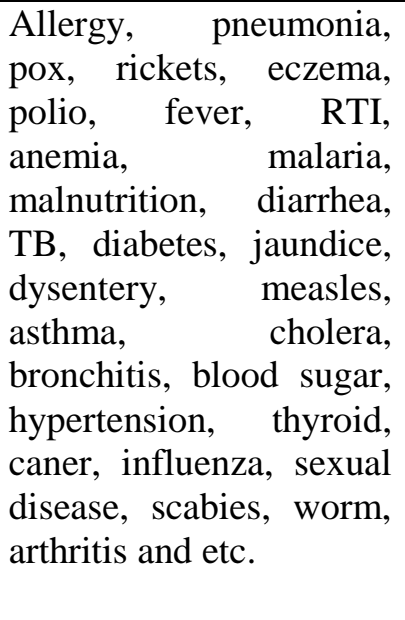 & 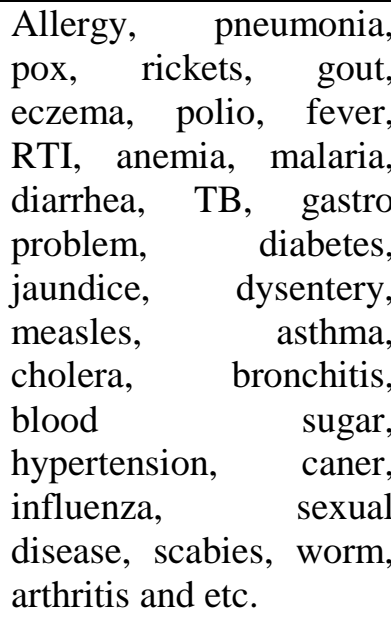 \\
\hline
\end{tabular}


Thalassemia Control by Awareness: A Study among the Educated Bengalee Populations of South 24 Parganas District, West Bengal, India

\begin{tabular}{|c|c|c|c|}
\hline 2 & $\begin{array}{l}\text { What kind of diseases the children are } \\
\text { suffering in your locality? }\end{array}$ & $\begin{array}{l}\text { Cough and cold, fever, } \\
\text { anemia, malaria, } \\
\text { malnutrition, diarrhea, } \\
\text { gastro } \\
\text { diabetes, problem, } \\
\begin{array}{l}\text { dysentery, jaundice, } \\
\text { asthma, measles, } \\
\text { bronchitis, influenza, } \\
\text { scabies, worm, arthritis } \\
\text { and etc. }\end{array}\end{array}$ & $\begin{array}{l}\text { Cough and cold, fever, } \\
\text { anemia, malaria, } \\
\text { malnutrition, diarrhea, } \\
\text { gastro } \\
\text { diabetes, problem, } \\
\text { dysentery, jaundice, } \\
\text { asthma, measles, } \\
\text { bronchitis, influenza, } \\
\text { scabies, worm, arthritis } \\
\text { and etc. }\end{array}$ \\
\hline 3 & $\begin{array}{l}\text { Have you seen/heard/known the } \\
\text { thalassemic child to whom blood is given } \\
\text { frequently? }\end{array}$ & Yes-25 (22.94) & Yes-137 (90.73) \\
\hline 4 & If yes, how many cases have you seen? & $\begin{array}{l}0-29(26.61), 1- \\
22(20.18), 2-29(26.61), 3- \\
7(6.42), 4-6(5.50), 5- \\
5(4.59), 6-1(0.92), 10- \\
2(1.84), \text { many-8(7.34) } \\
\text { Seen-109(100.00) } \\
\text { Not seen-0(0.00) }\end{array}$ & $\begin{array}{l}0-4(2.65), 1-41(27.15), 2- \\
35(23.18), 3-23(15.23), 4- \\
9(5.96), 5-3(1.99), \\
6-2(1.32), 10-2(1.32), 50- \\
1(0.66), 100-1(0.66) \text {, } \\
\text { many-15(9.93), some- } \\
2(1.32) \\
\text { Seen-138(91.39) } \\
\text { Not seen-13(8.61) }\end{array}$ \\
\hline 5 & $\begin{array}{l}\text { Do you think that these diseases are } \\
\text { transmitted from the parents or any other } \\
\text { sources? }\end{array}$ & $\begin{array}{l}\text { Parents-71(63.30), } \\
\text { parents \& other sources } \\
-3(2.75) \text {, don’t know - } \\
24(22.02) \text {, other sources } \\
-9(8.26) \text {, not always- } \\
2(1.84)\end{array}$ & $\begin{array}{l}\text { Parents-124(82.12), } \\
\text { parents \& other sources } \\
-1(0.66) \text {, don’t know - } \\
22(14.57) \text {, other sources } \\
-2(1.32) \text {, same blood } \\
\text { group-1(0.66), env. } \\
\text { Water-1(0.66) }\end{array}$ \\
\hline 6 & What are the genetic diseases? & $\begin{array}{l}\text { Thalassemia, blood } \\
\text { sugar, blood pressure, } \\
\text { diabetes, } \\
\text { hypertension, } \\
\text { hemophilia and others. }\end{array}$ & $\begin{array}{l}\text { Thalassemia, blood } \\
\text { sugar, blood pressure, } \\
\text { diabetes, } \\
\text { hypertension, } \\
\text { hemophilia and others. }\end{array}$ \\
\hline
\end{tabular}

\section{Knowledge:}

It is interesting to note that almost all of the educated Bengalee have heard the term 'thalassemia'. This is true for both the genders. They also know the symptoms of this disorder. But regarding mode of inheritance and relation of this disorder with blood, the females outnumber the males. While, $74.17 \%$ of the females know this as inherited disorder, $67.89 \%$ of

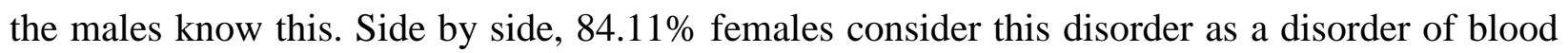


and $70.64 \%$ males consider this. Very few among them have the idea of different types of thalassemia and most of them do not know anything about thalassemia carrier. More than $91 \%$ of the males and $98 \%$ of the females believe carrier screening is necessary before marriage (Table 2).

Table 2: Knowledge about thalassemia

\begin{tabular}{|c|c|c|c|}
\hline \multirow[t]{2}{*}{ Sl.No. } & \multirow[t]{2}{*}{ Statements } & \multicolumn{2}{|c|}{$\begin{array}{l}\text { Response (qualitative, No. and percentage: } \\
n=260 \text { ) }\end{array}$} \\
\hline & & Male $(n=109)$ & Female $(n=151)$ \\
\hline 1 & Have you heard the term thalassemia? & Yes-108 (99.08) & Yes-151 (100.00) \\
\hline 2 & If yes, what are the symptoms? & $\begin{array}{l}\text { Anemia, pallor, fatigue, } \\
\text { weakness, tiredness, } \\
\text { shortness of breath, } \\
\text { jaundice, enlarge spleen, } \\
\text { enlarge liver, enlarge } \\
\text { heart, dark urine, weight } \\
\text { loss, decreased appetite, } \\
\text { rapid heartbeat, } \\
\text { headache, light } \\
\text { headedness, fever, belly } \\
\text { pain, chest pain, paleness } \\
\text { and etc. }\end{array}$ & $\begin{array}{l}\text { Anemia, pallor, fatigue, } \\
\text { weakness, tiredness, } \\
\text { shortness of breath, } \\
\text { jaundice, enlarge } \\
\text { spleen, enlarge liver, } \\
\text { enlarge heart, dark } \\
\text { urine, weight loss, } \\
\text { decreased appetite, } \\
\text { rapid heartbeat, } \\
\text { headache, light } \\
\text { headedness, fever, belly } \\
\text { pain, chest pain, } \\
\text { paleness and etc. }\end{array}$ \\
\hline 3 & From where you know about it? (source) & $\begin{array}{l}\text { School, college, books, } \\
\text { magazine, seminars, } \\
\text { awareness r camp, } \\
\text { hospitals, neighbors, } \\
\text { doctor, TV, radio, news } \\
\text { paper and etc. }\end{array}$ & $\begin{array}{l}\text { School, college, books, } \\
\text { magazine,, seminars, } \\
\text { awareness ramp, } \\
\text { hospitals, neighbors, } \\
\begin{array}{l}\text { doctor, TV, radio, news } \\
\text { paper and etc. }\end{array}\end{array}$ \\
\hline 4 & Is it an inherited disease? & Yes $74(67.89)$ & Yes112 (74.17) \\
\hline 5 & Is it a disorder of blood? & Yes77 (70.64) & Yes127 (84.11) \\
\hline 6 & $\begin{array}{l}\text { How many types of Thalassaemia are } \\
\text { there? }\end{array}$ & $\begin{array}{l}\text { 1-Nil,2-10(9.17),3- } \\
2(1.84), 4-1 \quad(0.92), \text { don't } \\
\text { know- 92(84.40),many- } \\
1(0.92)\end{array}$ & $\begin{array}{l}\text { 1-1(0.66),2-63(41.72),3- } \\
5(3.31), 4-2(1.32), \text { don’t } \\
\text { know-80(52.98) }\end{array}$ \\
\hline 7 & If yes, do you know the names? & $\begin{array}{l}\text { Alfa, beta }-3 \text {, don’t know } \\
-97(89.00) \text {, major and } \\
\text { minor-6(5.50), major, } \\
\text { minor and intermedia- } \\
3(2.76)\end{array}$ & $\begin{array}{l}\text { Alfa, beta }-22(14.57) \text {, } \\
\text { alfa, beta and alfa beta } \\
2(1.32) \text {, carrier and } \\
\text { healthy carrier-1(0.66), } \\
\text { don't know - 86(56.95), } \\
\text { forget- } 1(0.66) \text {, major } \\
\text { and minor- } 34(22.52) \text {, } \\
\text { major, minor and } \\
\text { intermedia -2(1.32), } \\
\text { thalssaemia A and B- } \\
2(1.32) \text {, thalassaemia A } \\
\text { and E-1(0.66) }\end{array}$ \\
\hline 8 & $\begin{array}{l}\text { Do you know anything about thalassemia } \\
\text { carrier? }\end{array}$ & 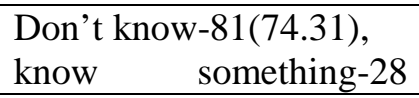 & $\begin{array}{l}\text { Don’t know-79 (52.32), } \\
\text { know something-72 }\end{array}$ \\
\hline
\end{tabular}


Thalassemia Control by Awareness: A Study among the Educated Bengalee Populations of South 24 Parganas District, West Bengal, India

\begin{tabular}{|l|l|l|l|}
\hline & \multicolumn{1}{|c|}{$(25.69)$} & $(47.68)$ \\
\hline 9 & $\begin{array}{l}\text { Can a normal person be a thalassemia } \\
\text { carrier? }\end{array}$ & Yes: 65 (59.63) & Yes: 106 (70.20) \\
\hline 10 & $\begin{array}{l}\text { Is there any treatment required for } \\
\text { thalassemia carrier? }\end{array}$ & Yes: 62 (56.88) & Yes: 70 (46.36) \\
\hline 11 & $\begin{array}{l}\text { Are there any physical abnormalities shown } \\
\text { by a thalassemia carrier? }\end{array}$ & Yes: 37 (33.94) & Yes: 42 (27.81) \\
\hline 12 & $\begin{array}{l}\text { Is there any thalassemia carrier necessarily } \\
\text { suffering from mental/physical illness? }\end{array}$ & Yes: 49 (44.95) & Yes: 59 (39.07) \\
\hline 13 & $\begin{array}{l}\text { Have you seen any mental/physical } \\
\text { abnormalities or disabilities among the } \\
\text { parents of thalassemia patients? }\end{array}$ & Yes: 24 (22.02) & Yes: 25 (16.56) \\
\hline 14 & $\begin{array}{l}\text { Do you know that thalassemia is usually } \\
\text { treatable but not curable? }\end{array}$ & Yes: 61 (55.96) & Yes: 90 (59.60) \\
\hline 15 & $\begin{array}{l}\text { Is carrier screening necessary before } \\
\text { marriage? }\end{array}$ & Yes: 100 (91.74) & Yes: 148 (98.01) \\
\hline 16 & $\begin{array}{l}\text { If yes. Whether it is mandatory/optional? } \\
\text { Whether a normal person can marry a } \\
\text { thalassemia carrier? }\end{array}$ & Yes: 55 (50.46) & Yes: 93 (61.59) \\
\hline 17 & \multicolumn{2}{|l|}{ Mandatory: 131 (86.75) } \\
\hline
\end{tabular}

\section{Attitude (social belief):}

A positive attitude is revealed in perception of thalassemia in both the genders (Table 3), as majority of the respondents said birth of a thalassemic child was not due to sins committed by the parents. More than $42 \%$ of the males and $45 \%$ of the females expressed that life becomes miserable for entire family if any one suffering from thalassemia in his/her family. Near about half of them described that they consider those family as unlucky where thalassemia occurs. Genetic counseling and awareness programme among these subjects is found to be very poor, which ranges between $0.66 \%$ and $5.3 \%$ (Table 3 ).

Table 3: Attitude (social belief)

\begin{tabular}{|l|l|l|l|}
\hline $\begin{array}{l}\text { Sl. } \\
\text { No. }\end{array}$ & Statements & $\begin{array}{l}\text { Male } \\
\text { Agree (n= 109) }\end{array}$ & $\begin{array}{l}\text { Female } \\
\text { Agree (n= 151) }\end{array}$ \\
\hline 1 & $\begin{array}{l}\text { A thalassemic child is born due to sin committed by } \\
\text { parents }\end{array}$ & $17(15.60)$ & $5(3.31)$ \\
\hline 1 & $\begin{array}{l}\text { The life becomes miserable for entire family, where } \\
\text { any one is suffering from thalassemia. }\end{array}$ & $46(42.20)$ & $68(45.03)$ \\
\hline 2 & $\begin{array}{l}\text { The family where someone is suffering from } \\
\text { thalassemia is unlucky. }\end{array}$ & $56(51.38)$ & $70(46.36)$ \\
\hline 3 & $\begin{array}{l}\text { It is better to die than live with a deadly disease } \\
\text { like; thalassemia. }\end{array}$ & $22(20.18)$ & $42(27.81)$ \\
\hline 4 & $\begin{array}{l}\text { I try to avoid a thalassemic patient. } \\
\text { Prenatal diagnosis is necessary for the carrier } \\
\text { couples. }\end{array}$ & $3(2.75)$ & $10(6.62)$ \\
\hline 6 & $\begin{array}{l}\text { Genetic counseling is required for pre-marriage, } \\
\text { pre-pregnancy and prenatal diagnosis. }\end{array}$ & $3(2.75)$ & $4(2.65)$ \\
\hline 7 & $\begin{array}{l}\text { Awareness programme is essential in every spheres } \\
\text { of life. }\end{array}$ & $3(2.75)$ & $1(0.66)$ \\
\hline
\end{tabular}




\section{Attitude (social distance):}

Respondents' statements according to social distance are furnished in table 4. Males differ with the females in different statements. Frequency of males (27.52\%) who agreed to live with a thalassemia person is higher than that of the females (15.89\%). The same is true for making friendship with a person suffering from thalassemia (male: 13.76\%; females 27.28\%). But a reverse trend is perceptible in case of feeling discomfort with a neighbour who is suffering from thalassemia (male: 17.43\%; female: 19.87\%) establishing marriage relation in a family where someone is suffering from thalassemia (male: $53.21 \%$; female: $64.90 \%$ ) and accepting a life partner having thalassemia trait/carrier (male: 66.97\%; female: 73.51). Thus, majority of the respondents were not willing to establish marriage relations with the family, having a sufferer and to marry a carrier.

Table 4: Attitude (social distance)

\begin{tabular}{|l|l|l|l|}
\hline Sl. & Statements & $\begin{array}{l}\text { Male (n= 109) } \\
\text { difficult }\end{array}$ & $\begin{array}{l}\text { Female (n= 151) } \\
\text { difficult }\end{array}$ \\
\hline 1 & $\begin{array}{l}\text { Living with a person who is suffering } \\
\text { from thalassemia. }\end{array}$ & $30(27.52)$ & $24(15.89)$ \\
\hline 2 & $\begin{array}{l}\text { Making friendship with a person who is } \\
\text { suffering from thalassemia. }\end{array}$ & $15(13.76)$ & $11(7.28)$ \\
\hline 3 & $\begin{array}{l}\text { Feeling discomfort with a neighbour, } \\
\text { who is suffering from thalassemia. }\end{array}$ & $19(17.43)$ & $30(19.87)$ \\
\hline 4 & $\begin{array}{l}\text { Establishing marriage relation in a } \\
\text { family where someone is suffering from } \\
\text { thalassemia. }\end{array}$ & $58(53.21)$ & $98(64.90)$ \\
\hline 5 & $\begin{array}{l}\text { Accepting a life partner having } \\
\text { thalassemia trait/carrier. }\end{array}$ & $73(66.97)$ & $111(73.51)$ \\
\hline
\end{tabular}

\section{Attitude (application):}

A good percent of the respondents (male: 68.81\%; female: 75.50\%) were found to discuss with their family members about thalassemia. Females outnumber the males ((males: 21(19.27\%); females $42(27.81 \%))$ in terms of testing of blood samples for thalassemia. The same is true in case of test of blood samples of family members for thalassemia. In case of attending awareness programme for thalassemia, $37.61 \%$ of the males and $34.44 \%$ of the females expressed positive response (Table 5). 
Table 5: Attitude (application)

\begin{tabular}{|l|l|l|l|}
\hline Sl. & Statements & $\begin{array}{l}\text { Response (qualitative, No. and percentage: } \\
\text { No. }\end{array}$ & \multicolumn{1}{|l|}{} \\
\cline { 3 - 4 } & & Male (n= 109) & Female (n= 151) \\
\hline 1 & $\begin{array}{l}\text { Did you ever discuss with your family } \\
\text { members about thalassemia? }\end{array}$ & $75(68.81)$ & $114(75.50)$ \\
\hline 2 & Have you tested your blood for thalassemia? & $21(19.27)$ & $42(27.81)$ \\
\hline 3 & $\begin{array}{l}\text { Have you tested blood of your family } \\
\text { members for Thalassaemia? }\end{array}$ & $14(12.84)$ & $34(22.52)$ \\
\hline 4 & $\begin{array}{l}\text { Have you attended any awareness } \\
\text { programme related to thalassemia? }\end{array}$ & $41(37.61)$ & $52(34.44)$ \\
\hline
\end{tabular}

\section{RECOMMENDATION:}

According to majority of the respondents' family level counseling is effective to combat thalassemia and awareness programme is more effective to control this disease. Majority of them also think that individual carrier screening is effective to control thalassemia (Table 6).

Table 6: Recommendation regarding awareness about thalassemia

\begin{tabular}{|l|l|l|l|}
\hline \multirow{2}{*}{$\begin{array}{l}\text { Sl. } \\
\text { No. }\end{array}$} & Statements & $\begin{array}{l}\text { Response (qualitative, No. and percentage: } \\
\mathbf{n}=\mathbf{2 6 0})\end{array}$ & \multicolumn{2}{l|}{} \\
\cline { 3 - 4 } & & Male (n= 109) & Female (n= 151) \\
\hline 1 & $\begin{array}{l}\text { Do you think that family level counseling is } \\
\text { effective to combat this disease? }\end{array}$ & Yes: 105(96.33) & Yes: 147(97.35) \\
\hline 2 & $\begin{array}{l}\text { Is awareness programme is more effective } \\
\text { to control this disease? }\end{array}$ & Yes: 100(91.74) & Yes: 148(98.01) \\
\hline 3 & $\begin{array}{l}\text { Do you think individual carrier screening is } \\
\text { effective to control thalassemia? }\end{array}$ & Yes: 88(80.73) & Yes: 142(94.04) \\
\hline
\end{tabular}

\section{CONCLUSION}

Present study is a quantitative description of knowledge, attitude and practice on thalassemia among the educated Bengalee in a high-risk area in West Bengal, India. The study subjects have a good knowledge about the deadly disease like thalassemia and treatment required for this. This is true for both the genders. But most of the respondents do not know about different types of thalassemia. Carrier screening is very much important in this area. Study reveals considerable difference between two genders in some particular issues. It is interesting to note that only 
$19.27 \%$ of the males and $27.81 \%$ of the females have tested their blood for thalassemia. Organizing awareness campaign is very much essential in this locality. The attitude towards thalassemia, social distance towards thalassemia, application and recommendation is very much positive and constructive to prevent/control the deadly disease like thalassemia. However, proper education and awareness programme with local community participation will be very effective as people witness the seriousness of this disease in their day to day life.

This study strongly supports extensive awareness about the disease among common mass, carrier screening of the general population before marriage, psycho-genetic counseling, prenatal diagnosis of the carrier couples, avoid marriages between carriers and avoid consanguineous marriages. The unmarried carriers are advised to have premarital blood testing of their proposed spouse, workshops at colleges, schools, nursing centers and other places, distribution of thalassemia books/leaflets to the publics and special attention to high risk families. Government health departments should implement carrier screening at the time of child immunization and counseling accordingly. If marriage occurs between two carriers and the couple do not want to undergo a prenatal diagnostic test it is better to adopt a child/ artificial insemination. By arranging seminar, lecture, exhibition, pathnatika (street drama), pupate show, video show etc. the nature of deadly disease like thalassemia can be conveyed nicely to the general people. Distribution of video CD on thalassemia to various health centers, anganwadi centers (child care centers), schools, colleges, and NGOs will be beneficial. Blood donation camps should be organized in different areas for the thalassemia patient. Awareness slogans may be displayed in the rural areas.

\section{ACKNOWLEDGEMENTS:}

This work is based on the project entitled, "Human Genetics Extension Programme - Beta Thalassaemia Study", which was approved by the Anthropological Survey of India, Kolkata. The authors are grateful to the said organization. Authors are grateful to all the elite groups in Falta Block, Diamond Harbour Block- I and Diamond Harbour Block- II of South 24 Parganas district of West Bengal who participated in this study.

\section{CONFLICT OF INTEREST}

The authors declare that there is no conflict of interest.

\section{REFERENCES:}

Basu Chakravarty, S. and Chakravarty, A. (2002). Genetics of Thalassemia Diagnosis, management and Prevention, Thalassemia Foundation, Kolkata.

Cao, A., Rosatelli, C., Pirastu, M., Galanello. R. (1991). Thalassemias in Sardinia: Molecular Pathology, Phenotype - genotype correlation, and prevention. Am J Pediatri Hematol Oncol, 13: $179-188$.

Durga Devi, N.K., Sai Sree, M., and Abhinaya, H. (2012). Screening analysis techniques and treatment strategies for haemoglobin $\mathrm{E}$ beta-thalassemia. Int. J Drug Research Techniques., 2(7): 472 -478. 
Fodde, R., Losekoot, M., Broek, M H van den, Oldenburg M., Rashida N., Sehreuder, A., Wijnen J. T., Giordano P.C., Nayadu, N. V., Khan, P. M. et al. (1988). Prevalence and molecular heterogeneity of alfa + thalassemia in two tribal populations from Andhra Pradesh, India. Human Gent, 80: 157 - 160.

Fucharoen, S., Winichagoon, P, (1992). Thalassemia in South East Asia: Problems and strategy for prevention and control. Southeast Asian J Trop Med Public Health, 23: 647 - 655.

Higgs D.R., Ayyub, H., Clagg, J.B., Hill, A.V., Nicholls R. D., Teal, H., Wainscoat, J.S., Weatherall, D. J. (1985). Alpha Thalassamia in British People. Br, Med J (Clin Rep Ed), 290: 1303-1306.

Karimi, M., Ghiam, A. F., Hashami, A., Alinejad, S., Soweid, M. and Kashef, S. (2007). Bone Mineral Density in Beta-Thalassemia Major and Intermdeia. Indian Pediatrics, 44(17): 29-32.

Lin, T.M., Eng, H.L., Kuo, P.L., Wu H.L. (1992). Neonatal screening for alpha-thalassemia in Southern Taiwan. J Formos Med Assoc., 91: 1213- 1215.

Slomp, J., Bosschaart, A., Dousma, M., Van, Z. R., Giordano, P. C., Bergh, F.A. Vanden. (2006). Acute anaemia in a Vietnamese patient with alpha-thalassaemia and a parvovirus infection. Ned Tijdschr Geneskd, 150: 1577- 1582.

Yagnik, H. (1997), Post counseling Follow up of Thalassemia in High Risk Communties, Indian Pediatrics, vol. 34: 1115-1118. 